\title{
KEPRIBADIAN ISLAMI DAN KUALITAS KEPEMIMPINAN
}

\author{
Ramon Ananda Paryontri \\ Universitas Ahmad Dahlan Yogyakarta
}

Tujuan penulisan makalah ini adalah membahas efek kepribadian Islam terhadap kualitas kepemimpinan. Indvidu yang memiliki kepribadian Islami akan memberikan dampak pada kualitas kepemimpinan khususnyacara individu dalam mengatur anggota atau kelompoknya. Makalah ini secara rinci akan membahas ruang lingkup kepribadian Islam, faktor-faktor yang mempengaruhi terbentuknya kepribadian Islam, aspek-aspek dari kepribadian Islam dan efeknya kepribadian Islami terhadap kualitas kepemimpinan seseorang. Kepribadian yang baik telah digambarkan dalam Al-Quran dan telah dicontohkan oleh Rasulullah SAW kepada individu muslim untuk membentuk suatu kepribadian yang baik. Kepribadian Islami merupakan gambaran ideal bagi individu muslim yang dapat menjalankan ajaran agama dengan baik. Kepribadian yang Islami ini pada akhirnya membentuk karakter yang mumpuni dan pada akhirnya mempengaruhi kualitas kepemimpinan dari diri individu itu. Kualitas kepemimpinan individu terhadap organisasi yang dipimpinnya dapat dilihat dari kematangan sosial, kematangan emosi, hubungan interpersonal yang baik, kemampuan dalam menyelesaikan masalah, dan ketepatan dalam membuat keputusan. Pada dasarnya, kualitas kepemimpinan sangat dipengaruhi oleh kepribadian yang baik dan kepribadian Islami merupakan kunci bagi individu dalam mengembangkan kualitas hidupnya, termasuk dalam hal kepemimpinan.

Kata Kunci: Kepribadian Islami, Kualitas Kepemimpinan

Abstract

The aim of writingthis paper is to discuss the effect of Islamic personality toward leadership quality. Individual that has Islamic personality will give effect on the leadership quality especially in the way he manages the members or the group. This paper will discuss in detail the scope of the Islamic personality, factors that affect the formation of the Islamic personality, personality aspects of islam and its effect on the quality of the leadership of the Islamic personality of a person. Good personality has been described in the Quran and exemplified by the Prophet Muhammad to form a good personality. Islamic personality is an ideal illustration for moslem individuals who can run with good religion. The Islamic personality ultimately shapes the powerful character and ultimately affects the quality of leadership of the individual him/herself. The quality of individual leadership to the organization he leads can be seen from the social maturity, emotional maturity, good interpersonal relationship, ability to solve problems, and accuracy in making decisions. Basically, the quality of leadership is strongly influenced by a good personality and Islamic personality is the key for individuals in developing the quality of life, including in terms of leadership.

Keywords: Islamic personality, leadership quality

\section{Latar Belakang}

Setiap individu memiliki kepribadian masing-masing yang berbeda-beda.Psikologi menyebutnya sebagai individual differences, yaitu individu yang unik dan memiliki kepribadian yang berbeda-beda. Kepribadian merupakan ciri khas seseorang yang meliputi sikap, perilaku, dan cara individu dalam menyelesaikan segala macam permasalahan dalam hidup. Kepribadian 
merupakan sesuatu yang tidak terlihat dan itu mencakup trait atau sifat pada diri invidu. Individu akan dipandang baik atau buruk tentu bisa dilihat dari kepribadian dan kepribadian itu bisa dilihat dari cara individu bersikap, berperilaku, berinteraksi dengan orang lain hingga cara menyelesaikan setiap masalah yang ada. Kepribadian juga menjadi aspek penilaian dalam lingkungan pendidikan maupun dunia kerja. Aspek kepribadian yang biasanya diterapkan dalam dunia pendidikan biasanya mencakup tiga ranah yaitu ranah kognitif, afektif, dan psikomotorik. Ketiga ranah itu menjadi penilaian dalam diri siswa selama siswa tersebut menjalankan kegiatan belajar mengajar di sekolah. Penilaian secara kepribadian ini memberikan penilaian yang seimbang dengan penilaian akademis bagi para siswa. Penilaian kepribadian dalam dunia kerja juga menjadi prioritas untuk menilai calon karyawan yang akan masuk kerja. Kriteria penilaian dalam kepribadian juga tidak lepas dari tiga ranah itu, ranah kognitif, afektif, dan psikomotorik. Karyawan yang memiliki kepribadian buruk biasanya akan kesulitan untuk bisa berkarir di perusahaan tersebut.Perusahaan menganggap bahwa kepribadian karyawan sangat mempengaruhi hasil kinerja perusahaan yang berhubungan dengan proses kinerja perusahaan berupa, keefektifan kinerja.

Keefektifan kerja merupakan suatu hal yang penting dalam mengembangkan budaya organisasi di suatu perusahaan. Keefektifan kerja mencakup bagaimana anggota suatu organisasi mampu bekerjasama dan berinteraksi antar satu dengan yang lain. Proses komunikasi pimpinan ke bawahan (top down) dan bawahan ke pimpinan (bottom up) menjadi suatu indicator apakah perusahaan tersebut mampu membuat budaya kerja yang efektif atau tidak. Terdapat suatu contoh bahwa terdapat perusahaan di Finlandia yang memiliki budaya organisasi yang baik dan pada akhirnya membawa pada keefektifan kerja pada karyawan yang ditunjukkan dengan kinerja yang terarah ( www. Jurnal-sdm.blogspot.com).Terdapat empat faktor yang mempengaruhi keefektifan kinerja yaitu: karakteristik organisasi, karakteristik lingkungan, karakteristik pekerja, dan karakteristik kebijaksanaan serta praktek manajemen. Faktor yang mempengaruhi dari keefektifan kerja itu adalah kualitas kepemimpinan. Kualitas kepemimpinan merupakan bagaimana cara dan komitmen pemimpin terhadap organisasinya atau kelompoknya sehingga pemimpin itu mendapatkan kepercayaan pada anggotanya. Kualitas juga mencakup sikap, kepribadian, gaya, sifat, dan karakter yang melekat pada diri individu (indonesiana.tempo.com).

Dalam sebuah survey yang dilakukan oleh IBM Institute for Business Value, para pemimpin perusahaan besar di dunia menyebut tiga kualitas kepemimpinan terpenting yang sangat diperlukan dalam lingkungan ekonomi sekarang maupun mendatang yaitu kreatifitas, integritas, dan kemampuan berpikir global. Kualitas yang disebutkan dalam tiga hal itu menjadi indikator para pelaku organisasi atau suatu kelompok di dunia ini dalam menilai terhadap kualitas seorang pemimpin. Hal ini seperti yang disampaikan di atas bahwa kualitas individu dalam bekerja dilihat dari ketiga ranah yang ada seperti kognitif, afektif, dan psikomotorik. Hal yang sama juga dilakukan dengan kualitas individu yang memperoleh jabatan sebagai pemimpin di suatu perusahaan maupun kelompok masyarakat. Seseorang dikatakan berkualitas dalam memimpin apabila memiliki kepribadian yang baik mencakup ranah kognitif, afektif, dan konatif. Permasalahan yang timbul adalah kepribadian yang baik tidak hanya mencakup ketiga aspek itu saja tetapi ada satu aspek yang belum tersentuh oleh banyak ahli dalam memberikan penilaian kepribadian seseorang. Ranah yang belum tersentuh itu adalah ranah spiritual (ruh) (Riyono, 2012). Ranah spiritual ini membawa seseorang dalam derajat yang lebih tinggi dan orang itu mampu mencapai komunikasi langsung dengan Sang Pencipta.

Apakah dengan ranah spiritual seseorang mampu memiliki kepribadian yang baik? Ranah spriritual lebih mengarahkan pada sikap dan perilaku yang selalu mengingatkan pada nilai-nilai Ketuhanan. Individu yang selalu ingat dengan nilai-nilai Ketuhanan maka akan membentuk kepribadian yang spiritual. 


\section{Pengertian Kepribadian Islami dan Kualitas Kepemimpinan}

Kepribadian adalah keseluruhan cara seorang individu bereaksi dan berinteraksi dengan individu lain (Alwisol, 2005). Kepribadian menurut psikologi terdiri dari banyak teori terutama yang diungkapkan oleh Allport ( ) bahwa kepribadian adalah suatu organisasi (berbagai aspek psikis dan fisik) yang merupakan suatu struktur dan sekaligus proses. Kepribadian merupakan sesuatu yang dapat berubah dan dapat tumbuh serta mengalami perubahan. Maslow (dalam alwisol, 2005) menyatakan bahwa kepribadian adalah sesuatu yang positif, tumbuh, berkembang, dan dapat mengaktualisasikan dirinya. Manusia dilihat sebagai sebagai makhluk yang dapat memilih segala hal dan mampu bertanggung jawab terhadap apa yang telah dipilihnya. Freud (dalam Alwisol, 2005) menyatakan bahwa kepribadian memiliki tiga struktur yang berinteraksi secara dinamis yang disebut sebagai id, ego, dan superego. Id merupakan struktur yang bersifat insiting dan harus dipuaskan secepat mungkin sehingga memiliki prinsip kesenangan (pleasure principle) (Ancok, 2004). Ego sebagai struktur yang melihat pada realitas menjadi mediator antara id dan superego. Superego sebagai struktur kepribadian yang melihat pada norma dan aturan-aturan moral di masyarakat.

Kepribadian pada manusia juga banyak faktor yang mempengaruhinya sehingga menjadi sebuah sifat (trait) pada diri orang itu. Faktor-faktor itu terdiri dari dua hal, yaitu faktor keturunan dan faktor lingkungan (www.wikipedia). Faktor keturunan mencakup tinggi badan, bentuk wajah, temperamen, tingkat energi, dan semuanya yang berhubungan dengan fungsi biologis dan dipengaruhi oleh orang tua dari individu tersebut. Faktor keturunan mencakup komposisi berupa biologis dan psikologis. Faktor lingkungan juga dapat memberi pengaruh yang besar terhadap kepribadian individu. Lingkungan membentuk karakter seseorang melalui norma, sikap, dan nilai yang ada di masyarakat. Pengaruh interaksi dengan keluarga, teman, dan kelompok sosial dapat menjadi pengaruh besar dari lingkungan yang akan mempengaruhi kepribadian individu itu. Kepribadian dapat dikatakan sebagai sebuah karakteristik yang mempengaruhi sikap dan perilaku kita dalam melakukan kegiatan sehari-hari baik itu di rumah, sekolah, organisasi, dan kelompok (Kartono, 2005). Pada dewasa ini telah banyak berbagai macam pelatihan yang dapat meningkatkan kepribadian individu (Ancok, 1994). Pelatihan seperti outbond akhir-akhir ini lebih popular dibandingkan dengan pelatihan yang sifatnya semi militer. Pelatihan yang menyenangkan yang dikombinasikan oleh permainan telah dirasa manfaatnya dalam membentuk kepribadian individu.

Pelatihan pembentukan kepribadian telah mulai dilakukan di lingkungan sekolah, perusahaan hingga lingkungan pegawai bahkan keluarga. Keluarga merupakan unit terkecil dalam masyarakat menjadi tempat bagi individu dalam pembentukan kepribadian yang positif (Muallifah, 2009). Keluarga merupakan lingkungan yang dianggap mampu mencetak individu sesuai dengan tahapan perkembangannya, mulai dari bayi sampai lansia. Penanaman nilai-nilai moral khususnya moral agama sering dilakukan dalam lingkup keluarga. Agama merupakan sumber dalam membentuk kepribadian positif tersebut. Pada dewasa ini, agama menjadi indikator yang utama dalam menilai moral dan akhlak seseorang. Nilai-nilai spiritual harus dimiliki oleh setiap individu sebagai modal yang baik dalam membangun kepribadian. Individu yang memiliki pemahaman agama yang baik tentu akan melakukan tindakan yang positif seperti membantu orang-orang yang disekitarnya, memperkuat hubungan yang baik dengan sesama, dan saling menghargai perbedaan pendapat yang ada serta mementingkan kepentingan orang banyak dibandingkan dengan kepentingan sendiri.

Kepribadian Islami merupakan akumulasi dari berbagai karakter dan sifat yang melekat pada diri individu yang berwujud pada perilaku sehari-hari yang mengarah pada nilai-nilai Islami. Kepribadian Islami terbentuk ketika individu memasuki tahap usia dini, yaitu dengan penanaman berbagai macam pengasuhan dari orang tua (Muallifah, 2009). Kepribadian Islami akan menghasilkan berbagai macam kecerdasan mulai dari kecerdasan intelektual, kecerdasan 
emosional, dan kecerdasan spiritual itu sendiri. Pembentukan kepribadian Islami tidak hanya terjadi di keluarga tetapi juga di lingkungan sekolah, masyarakat bahkan di lingkungan kerja. PT. Kereta Api Indonesia pernah melakukan pendidikan pesantren selama seminggu bagi karyawan yang beragama Islam untuk membentuk kepribadian Islam (Ancok, 1994). Karyawan yang telah mendapat pendidikan pesantren akhirnya memiliki moral yang sangat baik dan memiliki kinerja yang baik. Kepribadian Islami tidak memiliki perbedaan yang signifikan dengan konsep kepribadian pada umumnya. Perbedaan yang mendasar hanya pada konsep agama khususnya agama Islam yang memberikan dinamika berbeda pada diri individu.

Faktor-faktor yang membentuk kepribadian Islami terdiri dari:

1. Faktor Biologis

2. Faktor Sosial

3. Faktor Budaya

Ketiga faktor di atas sangat berpengaruh terhadap pembentukan kepribadian yang Islami pada diri individu. Ketiganya saling mempengaruhi dan terkait dengan pembentukan kepribadian seseorang.Faktor biologis merupakan genetik yang diturunkan dari orang tua ke anaknya. Orang tua yang religius lebih sering menyumbangkan anak yang religius pula. Orang tua yang suka melakukan tindak kekerasan tentu menjadikan anaknya juga suka melakukan hal yang sama. Faktor biologis tentu juga dipengaruhi oleh lingkungan sekitar atau faktor sosial. Individu yang dasarnya suka beribadah dan berdoa kepada Tuhan pada akhirnya bisa menjadi individu yang jauh dari agama ketika bergaul dengan lingkungan sosial yang tidak baik.Faktor budaya merupakan hasil interaksi antar masyarakat dengan lingkungan tempat tinggalnya. Ward ( 2008) menjelaskan bahwa ranah afektif, kognitif, dan perilaku dipengaruhi oleh kontak masyarakat antar budaya. Ranah spiritual juga dipengaruhi oleh budaya dari masyarakat setempat seperti nilai-nilai religius yang telah dianut lama oleh bangsa Indonesia. Sejarah Wali Songo yang memiliki karakter dan kepribadian baik serta mampu berdakwah agama Islam mampu menjadi model bagi sebagian umat Islam di Indonesia dalam menginternalisasi nilainilai keislaman. Masyarakat mampu menginternalisasi nilai-nilai keislamaan ketika masingmasing individu berinteraksi dengan lingkungan yang Islami. Lingkungan Islami ditunjukkan dengan adanya Masjid, pondok pesantren, dan majelis ta'lim. Budaya yang Islami terbentuk karena adanya interaksi antar masyarakat yang memiliki tujuan yang sama dalam menciptakan kehidupan yang Islam di lingkungan mereka.

Individu yang beragama Islam belum tentu memiliki kepribadian Islam jika individu tersebut tidak mampu dalam memahami ajaran islam secara menyeluruh (kaffah). Ajaran Islam yang sebenarnya menyeru kepada manusia agar menjadi rahmat bagi sekalian alam seperti yang digambarkan oleh Al-Quran tentang tujuan diutusnya Rasulullah SAW ke muka bumi ini.Individu yang mendalami ajaran Islam secara menyeluruh (kaffah) tentu memiliki bekal yang cukup untuk menjadi khalifah atau pemimpin di muka bumi ini. Manusia diberikan oleh Allah SWT sebagai makhluk yang mampu berpikir dengan baik, rasional, dan konstruktif. Karunia yang berupa akal itu seharusnya dapat dioptimalkan oleh sebagian besar manusia untuk mensejahterakan manusia yang lain bahkan dengan manusia yang tidak berkeyakinan sama. AlQuran mewajibkan manusia untuk menggunakan akalnya secara sehat sehingga mampu berpikir jernih dan selalu melakukan sesuatu hanya mencari ridha-Nya:

“Sesungguhnya dalam penciptaan langit dan bumi, dan silih bergantinya malam dan siang terdapat tanda-tanda bagi orang yang berakal, (yaitu) orang-orang yang mengingat Allah sambil berdiri atau duduk atau dalam keadaan berbaring dan mereka memikirkan tentang penciptaan langit dan bumi (seraya berkata):" Ya Tuhan kami,tiadalah Engkau menciptakan ini dengan sia-sia, Maha Suci Engkau, maka peliharalah kami dari siksa neraka" ( QS. Ali- Imran:3, 190-191). 
Ayat di atas menekankan kepada kita bahwa membentuk kepribadian Islam bermula dari bagaimana kita menggunakan akal pikiran kita dalam mempersepsi sesuatu. Berpikir positif merupakan kunci dalam membentuk karakter seorang muslim yang baik. Individu muslim harus dituntut untuk berpikir positif atau biasa disebut husnudzhon (berbaik sangka) kepada makhluk di sekitarnya termasuk dengan Allah SWT. Berbaik sangka terhadap Allah SWT merupakan ekspresi keimanan seseorang terhadap Allah SWT yang telah melimpahkan karunia-Nya kepada kita ( Bantinie, 2010). Berpikir negatif sebaliknya, akan menimbulkan dosa besar, membuat kita menjadi pesimis dalam menjalani hidup, kehilangan harapan, dan putus asa. Banyak individu yang mengalami kepribadian buruk, tidak mampu berinteraksi dengan orang lain disebabkan selalu su'udzon terhadap Allah SWT dan orang lain. Sikap dan perilaku su'udzon terhadap Allah SWT dan orang lain membuat individu tersebut mengalami masalah dan kesulitan dalam hidup sehingga mudah terkena gangguan psikologis seperti stres, depresi, dan penyakit mental lainnya. Salah satu Hadist juga disampaikan tentang berpikir positif ini:

“Aku berdasarkan prasangka hamba-Ku kepada-Ku." ( HR. Muslim )

Hadist di atas memberikan kepada kita penjelasan bahwa Allah SWT akan memberikan kepada kita jika kita mau meminta secara baik, halus, santun dan yakin bahwa Allah SWT akan mengabulkan doa kita.

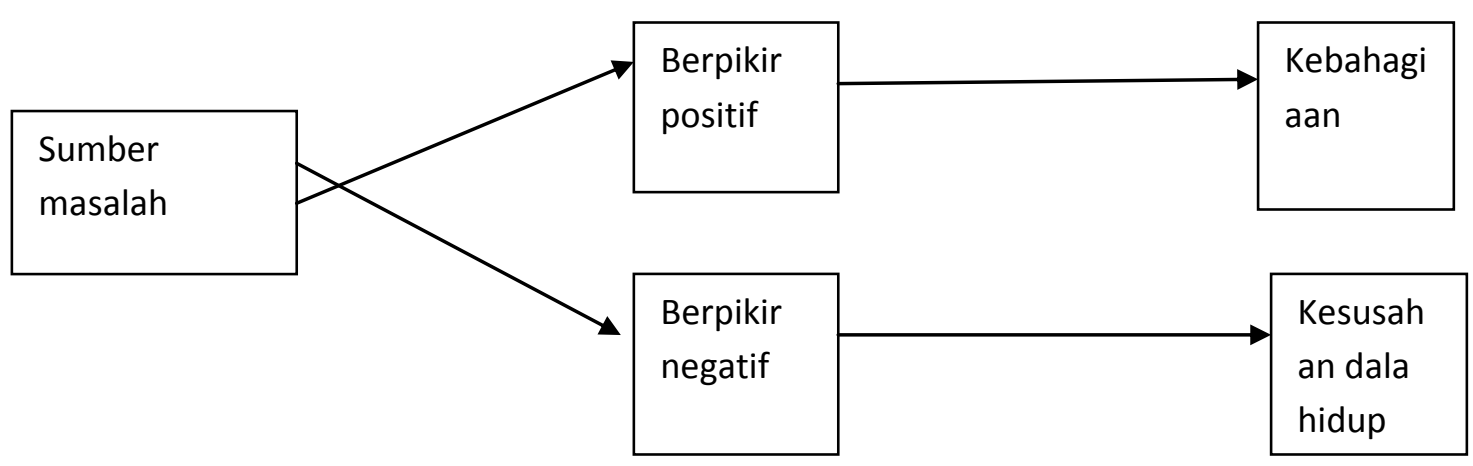

Dari bagan di atas dapat dijelaskan bahwa kebahagiaan dan kesusahan dalam hidup tergantung bagaimana individu dalam merespon dengan akalnya terhadap masalah tersebut.Akal yang baik tentu mengarahkan individu untuk selalu berpikir positif dan akal yang buruk akan mengarahkan individu untuk berpikir negatif.Kepribadian Islam merupakan kepribadian yang terbentuk melalui akal, perasaan, sikap, bahasa, budaya dan nilai sosial.Allah SWT mengajarkan kepada kita untuk mempergunakan kecerdasan kita dengan sebaik-baiknya dan mampu memahami orang lain dengan baik .

Kepribadian Islam juga memiliki aspek-aspek yang mendasarinya pada diri manusia:

1. Aspek-aspek kejasmanian meliputi tingkah laku luar yang mudah nampak dan ketahuan dari luar, misalnya cara berbuat, berbicara, dan sebagainya.

2. Aspek-aspek kejiwaan meliputi aspek-aspek yang tidak segera dapat dilihat dan ketahuan dari luar, misalnya: cara-caranya berfikir, sikap, dan minat.

3. Aspek-aspek kerohanian yang luhur: meliputi aspek kejiwaan yang lebih abstrak yaitu filsafat hidup dan kepercayaan. Hal ini meliputi sistem nilai yang telah meresap dalam kepribadian, yang telah menjadi bagian dalam kepribadian dan memberi corak seluruh individu tersebut (Hasan, 2000).

Aspek pertama menjelaskan kepada kita bahwa individu yang beribadah kepada Allah SWT akan terlihat pada perilaku sehari-harinya, bagaimana dalam berbicara dan berbuat, hal itu semua akan membentuk kualitas diri individu tersebut. Wujud dari nilai-nilai ibadah akan lebih baik ketika mampu dimanifestasikan dalam perilaku sehari-hari. Melaksanakan shalat lima waktu, aktif di kegiatan kemasyarakatan, serta melakukan amalan-amaala sholih lain merupakan 
wujud dari menifestasi ibadah itu. Aspek kedua, lebih kepada penekanan hal-hal yang bersifat abstrak sebagai wujud dari terbentuknya kepribadian Islam. Psikologi Islam lebih membahas manusia pada aspek yang ini, yaitu melihat manusia melakukan proses berpikir, mempersepsi sesuatu, memiliki sikap, keinginan, minat dan bakat yang dilandasi oleh nilai-nilai spiritual. Psikologi Islam melihat aspek kejiwaan sebagai nafs (jiwa) yang sifatnya tidak dapat dilihat tetapi ada dalam diri manusia yang telah memiliki jiwa Keislamaan luhur (Riyono, 2012). AlGhazali (dalam Hasan, 2000) menyebutkan bahwa dalam pandangan Islam, setiap individu menginginkan dua hal, yaitu kesenangan hidup an ketenangan hidup. Orang yang memiliki kesenangan hidup belum tenu memiliki ketenangan hidup dan orang yang memiliki ketenangan hidup pasti telah memperoleh kesenangan hidup. Seseorang mungkin senang memiliki uang yang banyak tetapi terkadang tidak mampu atau bingung dalam penggunaan uang itu yang pada akhirnya orang itu merasa tidak mengalami ketenangan dalam hidup. Ketenangan hidup akan membimbing manusia dalam mencapai kepribadian yang kuat, selalu berpikir positif, dan selalu merasa dekat dengan Allah SWT. Aspek ketiga, sifatnya lebih asbtrak dalam memaknai kejiwaan manusia, khususnya dalam hubungannya dengan Sang Pencipta. Nilai-nilai keislamaan lebih mengakar secara holistik dalam diri manusia sehingga lebih membentuk keprbadian individu secara Islam. Penghayatan, pengamalan, dan pemaknaan individu terhadap keislamaan sangat tinggi seperti seorang sufi yang mampu mengintegrasikan antara akal, afek, dan fisik. Individu merasa seperti berpisah dengan kehidupan dunia dan sangat dekat dengan hubungan vertikal, yaitu dengan Sang Pencipta ( Frager, 2014). Individu seperti itu biasanya selalu berada di tempat yang tenang dan selalu berdzikir kepada Allah SWT serta berorientasi selalu pada kehidupan akhirat.

\section{Kualitas Kepemimpinan}

Era sekarang merupakan masa persaingan yang sangat kompetitif dalam segala bidang khususnya bidang pekerjaan. Dunia industri atau pekerjaan, selalu dituntut mulai dari level karyawan sampai level top manajemen untuk memiliki kapasitas dalam mengelola perusahaan tempat bekerja. Perusahaan atau industri yang diisi oleh pegawai yang kurang inovatif akan mengalami kemunduran dalam bersaing dengan industri lain. Banyak industri mengalami kemunduran bahkan gulung tikar disebabkan oleh beberapa hal, diantaranya: minimnya inovasi dari karyawannya, kurangnya fasilitas dan keuangan organisasi, dan yang paling utama, minimnya kualitas seorang pemimpin yang memimpin organisasi atau perusahaan itu. Suatu organisasi baik itu organisasi perusahaan, organisasi kemasyarakatan, LSM hingga negara pasti memiliki seorang pemimpin dalam menggerakkan roda kebijakan organisasi itu. Seorang pemimpin juga harus memiliki kualitas yang berupa inovatif, kreatifitas, dan manajerial yang baik. Pemimpin juga harus memiliki etos kerja yang kuat dan mampu berkoneksi dengan bawahannya serta memiliki jaringan yang luas (Ancok, 2012). Banyak pakar mengatakan bahwa pemimpin merupakan nahkoda dalam menggerakkan organisasi yang dipimpinnya sehingga harus terus meningkatkan kemampuannya dalam memimpin. Kemampuan dalam berbagi pengetahuan dalam organisasi juga merupakan salah satu kapasitas yang harus ditingkatkan oleh pemimpin agar mampu mengembangkan organisasi yang berbasis pengetahuan (Helmi, 2010). Pada dunia bisnis yang berbasis pengetahuan, hanya perusahaan yang bisa mengelola perusahaanlah yang akan sukses. Peran seorang pemimpin sangat vital khususnya dalam memotivasi dan menginspirasi bawahannya sehingga bawahannya merasa dimanusiakan dan mampu bekerja secara optimal. Menurut Bass (dalam Ancok, 2012) menyatakan bahwa untuk meningkatkan kualitas kepemimpinannya di perusahaan, maka pemimpin perlu mengkombinasikan gaya kepemimpinan transformational sehingga akan memunculkan banyak inovasi dalam perusahaan. Terdapat empat cirri kepemimpinan transformasional, yaitu intellectual stimulation, idealized influence, inspiring motivation, dan individual consideration, 
yang itu semua akan membuat pemimpin memiliki visi jauh ke depan dalam membangun sebuah organisasi.

Bangsa Indonesia memiliki sebuah budaya yang baik, halus, dan santun dalam berinteraksi antar sesame manusia. Pemimpin yang baik juga harus menerapkan budaya seperti itu ketika di organisasi yang dipimpinnya sehingga bangsa kita tidak kehilangan identitasnya sebagai bangsa yang besar. Pada saat ini, sering bermunculan gaya kepemimpinan yang semenamena dalam menginstruksikan pada anak buahnya sehingga akan memperburuk citra kualitas pemimpin itu sendiri. Banyak akhirnya orang yang membedakan antara bos dan pemimpin (leader) dan semua itu sangat terlihat perbedaannya yang besar. Bos merupakan seorang yang memegang jabatan dan bawahannya harus patuh kepadanya tanpa harus banyak membantah apa saja yang diperintahkan sedangkan pemimpin (leader) merupakan individu yang memiliki kemampuan memimpin dalam organisasi dengan banyak memberi stimulus pada bawahannya sehingga visinya pada perubahan organisasi serta peningkatan kualitas dirinya sendiri. Budaya yang santun yang dilandasi nilai-nilai Ketuhanan telah diajarkan oleh bangsa kita selama bertahun-tahun ini harus mampu diaplikasikan oleh para pemimpin yang mengelola organisasi yang ditempati. Indonesia merupakan negara beragam, beradab, dan bermoral tentu harus diisi oleh para individu yang mampu menjadi pemimpin yang berlandaskan nilai-nilai agama khususnya agama Islam. Kepemimpinan dalam Islam telah dicontohkan oleh Rasulullah SAW dalam membina umat dari masa jahiliyah hingga masa pencerahan. Dakwah Rasulullah SAW telah mampu dimaknai oleh seluruh umat Islam di dunia termasuk di Indonesia sebagai bangsa dengan populasi muslim terbesar. Rasulullah SAW telah sukses menjadi pemimpin yang adil, berwibawa, dan juga santun terhadap umatnya. Kepribadian yang baik telah menjadikan Rasulullah SAW menjadi suritauladan yang baik, bahkan menjadi rahmat bagi manusia (rahmatan linnas) dan rahmat bagi alam (rahmatan lil'alamin). Allah SWT berfirman:

"Sesungguhnya telah ada pada diri Rasulullah itu suri tauladan yang baik bagimu (yaitu) bagi orang yang mengharap (rahmat) Allah dan (kedatangan) hari kiamat dan dia banyak menyebut Allah" (QS. Al-Ahzab (33):21).

Pada dasarnya setiap manusia adalah pemimpin, setidaknya menjadi pemimpin bagi dirinya sendiri secara holistik dan setiap kepemimpinan akan diminta pertanggungjawabannya di akhirat kelak. Pemimpin yang memiliki kualitas rendah, yang hanya bermodalkan suruh menyuruh tanpa memanusiakan manusia, akan menjadi pemimpin yang kurang amal di hari akhir nanti. " Ingatlah, setiap kamu adalah pemimpin dan akan dimintai pertanggungjawabannya tentang kepemimpinan, seorang suami adalah pemimpin keluarganya dan ia akan dimintai pertanggungjawabannya, wanita adalah pemimpin bagi kehidupan rumah tangga suami dan anak-anaknya, dan ia akan dimintai pertanggungjawabannya tentang kepemimpinannya itu". Perspektif Islam menegaskan bahwa seorang pemimpin yang baik adalah pemimpin yang memiliki empat sifat, yaitu Siddiq (dapat dipercaya), Tabligh (kemampuan berkomunikasi), Amanah ( bertanggung jawab), dan Fatanah (cerdas) ( www.idid.facebook.com/smpislamterpadu.com). Empat pilar sifat di atas merupakan kualitas kepemimpinan bagi seorang muslim dalam mengelola organisasi yang demikian kompleks sehingga umat Islam tidak ketinggalan dalam memajukan sebuah organisasi dari berbagai macam sektor. Hal lain yang menjadi perhatian bagi kualitas pemimpin yang memiliki jiwa keislmaan adalah memperhatikan musyawarah, keadilan, dan kebebasan berfikir. Pemimpin yang memiliki jiwa Islam yang kaffah tentu bukanlah seorang pemimpin bersifat tirani dan tanpa memperhatikan bawahannya. Islam selalu mengajarkan kepada manusia bahwa tolong menolong dan bekerja sama akan membantu manusia menjadi hidup sejahtera ( Ancok, 1994).Pemimpin muslim harus mampu bermusyawarah dan menghargai pendapat dari bawahannya serta memberikan kebebasan berpikir untuk menemukan ide-ide yang inovatif. 
Permasalahan seperti kurang efektifnya komunikasi antara atasan dan bawahan, konflik antar karyawan bisa diatasi jika pemimpin memiliki kualitas yang mumpuni berdasarkan AlQuran dan Sunnah. Allah SWT berfirman: "Ingatlah ketika Tuhanmu berfirman kepada para malaikat:" Sesungguhnya Aku hendak menjadikan seorang khalifah di muka bumi". Mereka berkata: "Mengapa Engkau hendak menjadikan (Khalifah) di muka bumi itu orang yang akan membuat kerusakan padanya dan menumpahkan darah, padahal kami senantiasa bertasbih dengan memuji Engkau dan mensucikan Engkau?” Tuhan berfirman: “ Sesungguhnya Aku mengetahui apa yang tidak kamu ketahui”. (Al-baqarah(2):30). Ayat ini menegaskan bahwa Allah SWT akan menjadikan umat manusia yang akan menjadi khalifah/pemimpin di muka bumi ini meskipun sempat ditentang oleh para Malaikat. Ayat di atas menegaskan pembahasan di awal makalah ini bahwa manusia memiliki struktur kognitif yang kompleks sehingga manusia mampu berpikir dengan nilai-nilai rasional. Konsep pemimpin dalam Islam tidak hanya berada di suatu organisasi saja tetapi dimanapun kita berada manusia tetaplah seorang pemimpin baik itu di rumah, keluarga, atau dalam ibadah Shalat. Shalat merupakan ibadah yang menjadi tiang agama Islam dan memerlukan seorang pemimpin atau Imam dalam aktivitas ibadahnya. Makmum dalam Shalat dilarang mendahului imam dan harus mengikuti gerakan imam sehingga akan tercipta koordinasi yang efektif antara imam (atasan) dengan bawahannya (makmum) tanpa harus melakukan komunikasi ( haryanto, 2004).Pemimpin yang tidak mampu menjaga kewibawaan atau terlalu bertindak sewenang-wenang di hadapan bawahannya maka akan menimbulkan berbagai macam konflik yang berkepanjangan baik dari konflik personal maupun konflik organisasi. Pemimpin yang berkualitas tentu harus selalu mengkombinasikan dan mengeluarkan seluruh jiwa dan fisiknya dalam membangun suatu organisasi yang mapan. Pemimpin yang baik tidak hanya memikirkan bagaimana tentang dirinya sendiri tetapi juga memikirkan anak buahnya seperti yang dicontohkan oleh khalifah Umar bin Khatab. Khalifah Umar tidak akan pernah tidur nyenyak sebelum seluruh rakyatnya kenyang perutnya dengan cara sang pemimpin melakukan keliling seluruh sudut kota untuk memastikan apakah rakyatnya sudah makan atau belum. Kualitas pemimpin bisa dilihat dalam menyelesaikan masalah, melakukan penilaian yang akurat terhadap bawahannya, memotivasi anak buahnya, dan membuat keputusan yang cepat. Banyak ahli melihat kualitas pemimpin hanya dari aspek kognitif saja tanpa memperhatikan aspek-aspek lain yang berpengaruh khususnya aspek spiritual.

\section{Efek Kepribadian Islam Terhadap Kualitas Kepemimpinan}

Kepribadian manusia yang positif ternyata telah terbukti mampu membuat manusia berguna di lingkungan masyarakatnya tidak terkecuali di lingkungan organisasi tempat dia berada. Terdapat banyak sekali manfaat memiliki pribadi yang ulet, terampil, dan individu tersebut memiliki pengaruh yang luar besar terhadap kesejahteraan manusia khususnya dalam organisasi. Individu yang positif di segala aspek baik kognitif, afektif maupun konatif tentu memiliki kemampuan dalam menyelesaikan masalah yang cepat di dalam organisasi tanpa mengorbankan individu yang lain yang juga bekerja di organisasi tersebut. Ketiga aspek di atas, kognitif, afektif, dan konatif merupakan ranah bagi individu dalam mengembangkan potensinya baik bagi dirinya sendiri dan bagi orang lain. Psikologi barat yang menganut paham sekuler selalu mengungkap ketiga aspek atau ranah itu dalam melihat perkembangan manusia. Permasalahan yang terjadi adalah ketiga ranah tersebut tidak mampu bersinergi dalam melihat perkembangan manusia. Ketiga aspek tersebut tidak mampu berintegrasi secara holistik sehingga manusia tidak mampu mencapai suatu kepribadian yang utuh (Riyono,2012). Individu yang memiliki kemajuan dalam ranah kognitif terkadang lemah dalam aspek afektif atau individu kuat secara konatif tetapi lemah dalam aspek kognitif. Manusia harus memerlukan aspek yang mampu melihat kepribadian secara keseluruhan tidak terbelah-belah seperti atas, maka aspek spiritual merupakan solusi untuk melihat kepribadia manusia secara utuh. Aspek 
spiritual menjadikan manusiamemiliki kepribadian yang terintegrasi secara holistik sehingga manusia mampu berperilaku dengan terencana dan terstruktur (Jaenudin, 2012). Nilai-nilai spiritual akan membantu jiwa kita untuk lebih dekat dengan sang Pencipta yang akan membawa manusia pada derajat yang lebih tinggi serta mampu berperilaku sesuai dengan ajaran agamanya ( Frager, 2014).

Aspek spiritual tentu harus mutlak dimiliki oleh individu yang menjadi pemimpin di sebuah organisasi. Pemimpin yang cerdas harus memiliki jiwa yang kuat berlandaskan nilainilai keagamaan yang menuntunnya untuk selalu berpikir, berperasaan, dan berperilaku secara positif.Ibnu Khaldun (dalam Riyono, 2012) mengatakan bahwa kepemimpinan merupakan struktur organisasi yang berguna untuk menata ketertiban umum supaya manusia tidak saling menyakiti dan melukai. Ibnu Khaldun menegaskan bahwa manusia bisa lebih buas daripada binatang ketika sudah muncul jiwa agresinya dan jiwa agresi akan muncul ketika manusia jauh dari nilai-nilai spiritual. Emosi, amarah, dendam, dengki, bahkan membunuh merupakan cara syetan dalam mengganggu manusia yang terpisah dengan nilai-nilai spiritual. Agama Islam merupakan agama yang selalu mengajak manusia untuk terus mengingat Allah SWT setiap saat sehingga nilai-nilai spiritual lebih mampu membentuk kepribadian yang agamis.Pemimpin yang matang secara spiritual tentu akan lebih mampu menata kehidupan organisasinya dengan baik, sabar dalam melayani bawahannya, dan dapat menata pemerintahan dengan bersih. Kualitas pemimpin yang baik akan terlihat juga bagaimana cara pemimpin tersebut menyelesaikan masalah dengan cepat dan akurat. Hasil dari penelitian di 46 orang Afrika Amerika menyebutkan bahwa individu yang memiliki penyelesaian masalah secara negatif akan lebih cepat kehilangan, sering melakukan amarah terhadap Tuhan mereka, dan kehilangan nilai-nilai spiritual dengan cepat (Burke, Neimeyer, Murphy, Ippolito, dan Roberts, 2011). Kepribadian Islam akan membantu individu dalam meningkatkan kualitas hidupnya mulai dari penyelesaian masalah yang positif, memiliki motivasi yang tinggi hingga individu tersebut mampu mengaktualisasikan dirinya. Maslow ( dalam Jaenudin, 2012) menyatakan bahwa aktualisasi diri manusia merupakan puncak tertinggi pada hirarki manusia dalam mengeluarkan segala potensinya. Maslow sendiri tidak menyentuh ranah spiritual dalam melihat puncak hirarki tersebut dan juga tidak memungkiri bahwa ada yang lebih tinggi lagi dalam pembentukan kepribadian yang tertinggi. Pemimpin merupakan individu dalam mengaktualisasikan dirinya dan mengeluarkan segala potensinya sehingga dirinya menjadi tumpuan bagi individu lain dalam melakukan kegiatan. Pemimpin yang baik tidak hanya melihat amanah yang diembannya sebagai nafsu untuk mencari kekuasaan semata dan jabatan yang akan dibawa hingga mati tetapi lebih kepada pemaknaan hidup sebagai seorang pemimpin. Pemimpin dalam perpektif Islam harus memiliki jiwa sabar, amanah, fathanah, dan tabligh dalam menjalankan roda organisasi. Hal ini pernah dicontohkan oleh Rasulullah SAW dan para sahabat dalam menjalankan suatu kepemimpinan yang suatu kepemimpinan. Nabi Muhammad SAW saat diangkat menjadi rasul telah dibekali dengan semangat keilmuan yang tinggi, hikmah, dan keimanan. Rasulullah SAW berdakwah dengan memegang teguh empat sifat di atas sehingga dakwah beliau selama 23 tahun mampu diterima oleh sebagian orang-orang kafir Quraisy pada waktu itu. Kesabaran yang ditampilkan Rasulullah SAW dalam menjadi pemimpin bagi para sahabat dalam menyebarkan Islam dapat dicontoh oleh pemimpin di zaman sekarang khususnya di Indonesia. Kemampuan dalam menyelesaikan konflik di tengah masyarakat Arab yang saat itu masih dipenuhi dengan perilaku buruk seperti khamr dan mengubur bayi yang hidup serta melakukan komunikasi yang efektif dengan para sahabat dan para kaum kafir quraisy merupakan sosok kualitas kepemimpinan yang dibangun melalui kepribadian Islam.

\section{Penutup}

Pemimpin yang berkualitas sangat tepat jika diterapkan di masyarakat kita di tengahtengah krisis kepemimpinan yang ada sekarang ini. Bangsa Indonesia saat ini membutuhkan 
seorang pemimpin yang memiliki kualitas mumpuni, kredibel, peka terhadap masalah, serta mampu mengayomi rakyatnya dengan baik tanpa mendzoliminya. Bangsa kita telah mengalami krisis multidimensi berkepanjangan dikarenakan tidak adanya sosok pemimpin yang membawa perubahan besar untuk bangsa kita dalam menghadapi krisis itu. Figur seorang pemimpin yang menjadi model bagi rakyatnya telah gagal memberi pengaruh yang kuat dalam menyatukan rakyat di atas nilai-nilai budaya santun bangsa ini yang telah terbentuk selama bertahun-tahun. Pemimpin yang seharusnya mampu menyatukan rakyat tetapi malah justru membawa rakyat ke jurang penderitaan yang sangat besar. Figur pemimpin telah dipersepsikan oleh rakyat sebagai sosok yang memberi ancaman kepada mereka sehingga rakyat telah kehilangan kepercayaan (trust) kepada pemimpinnya sendiri. Permasalahan yang terjadi ketidakmampuan pemimpin bangsa ini diimitasi atau ditiru oleh para pemangku kebijakan di tingkat provinsi, kota, kabupaten, hingga sekolah sampai perusahaan. Banyak para pemimpin di berbagai ranah itu kurang mampu memberikan kesejahteraan bagi bawahannya dan tidak jarang para pemimpin itu justru tersandung berbagai masalah sendiri. Hasilnya banyak organisasi menjadi organisasi yang apatis dan eksklusif, tidak mau berbagi pengetahuan dengan organisasi lain. Pembahasan di awal sudah dijelaskan bahwa organisasi yang maju harus memiliki pemimpin yang selalu merangsang inovatif dan selalu berbagai pengetahuan terhadap bawahannya. Ketika berbicara kepemimpinan dala psikologi, tentu selalu melihat dari ketiga ranah yang utama dalam meilai sosok pemimpin itu kompeten atau tidak. Ranah kognitif, afektif, dan konatif merupakan ketiga ranah yang selalu dibahas dalam psikologi barat yang memang melihat manusia merupakan individu yang terbagi-bagi antara ketiga ranah/aspek itu. Ketiga ranah tersebut ternyata belum mampu menampilkan sosok pemimpin yang berkualitas seperti yang diinginkan oleh bangsa kita. Ranah spiritual yang melihat aktivitas manusia berlandaskan nilai-nilai agama merupakan ranah yang belum pernah disentuh oleh psikologi barat. Pada perkembangan ilmu psikologi, sudah ada tokoh-tokoh besar psikologi yang menyentuh ranah spiritualitas pada manusia dalam perilakunya seperti William James, Carl G. Jung, dan Stanley hall. Psikologi saat itu masih dikuasai oleh aliran fungsionalisme dan strukturalisme dalam memahami keadaan manusia di setiap aktivitasnya. Aliran ini akhirnya dipatahkan oleh behaviorisme yang inti dari aliran itu adalah ingin melihat manusia secara nyata dan mampu ditangkap oleh mata. Perkembangan ilmu psikologi akhirnya mengkombinasikan antara psikis dan perilaku untuk memahami manusia termasuk dalam membahas masalah kepemimpinan.

Ranah spiritual yang melihat manusia melalui pemaknaan pada nilai-nilai agama mampu mengungkap sosok kepribadian yang agamis yang pada akhirnya akan berdampak pada perilaku individu dalam memimpin. Individu yang memiliki kepribadian berbasis nilai-nilai agama harus mampu diimplementasikan dalam wujud perilaku individu tersebut dalam melakukan kepemimpinan. Cara memimpin individu akan menjadi indikator yang dilihat dan diinterpretasikan oleh banyak orang termasuk dengan bawahannya. Individu yang selalu mengingat Sang Khalik tentu tidak akan pernah menyia-nyiakan posisinya sebagai pemimpin karena jabatan pemimpin itu adalah amanah yang akan dipertanggungjawabkan di akhirat kelak. Sama seperti yang disampaikan salah satu Hadits yang shahih tentang seorang pemimpin yang akan dimintai pertanggungjawabannya kelak. Kualitas pemimpin sangat ditentukan oleh kepribadian berlandaskan agama khususnya Islam yang memang banyak sekali mencontohkan kita dengan tokoh-tokoh hebat yang mampu menjadi pemimpin atau khalifah di bumi ini. Rasulullah SAW merupakan contoh terbesar bagi bangsa kita yang mayoritas muslim ini untuk dapat dicontoh kualitas kepemimpinannya. Keteladanan, kecerdasan, kesabaran, komunikasi yang efektif, kemampuan mengelola masyarakat Arab yang majemuk dan saat itu masih zaman jahiliyah, merupakan sosok pribadi Islam yang memberikan pengaruh atau efek terhadap kepemimpinan yang bekualitas di masyarakat yang majemuk seperti bangsa kita. 


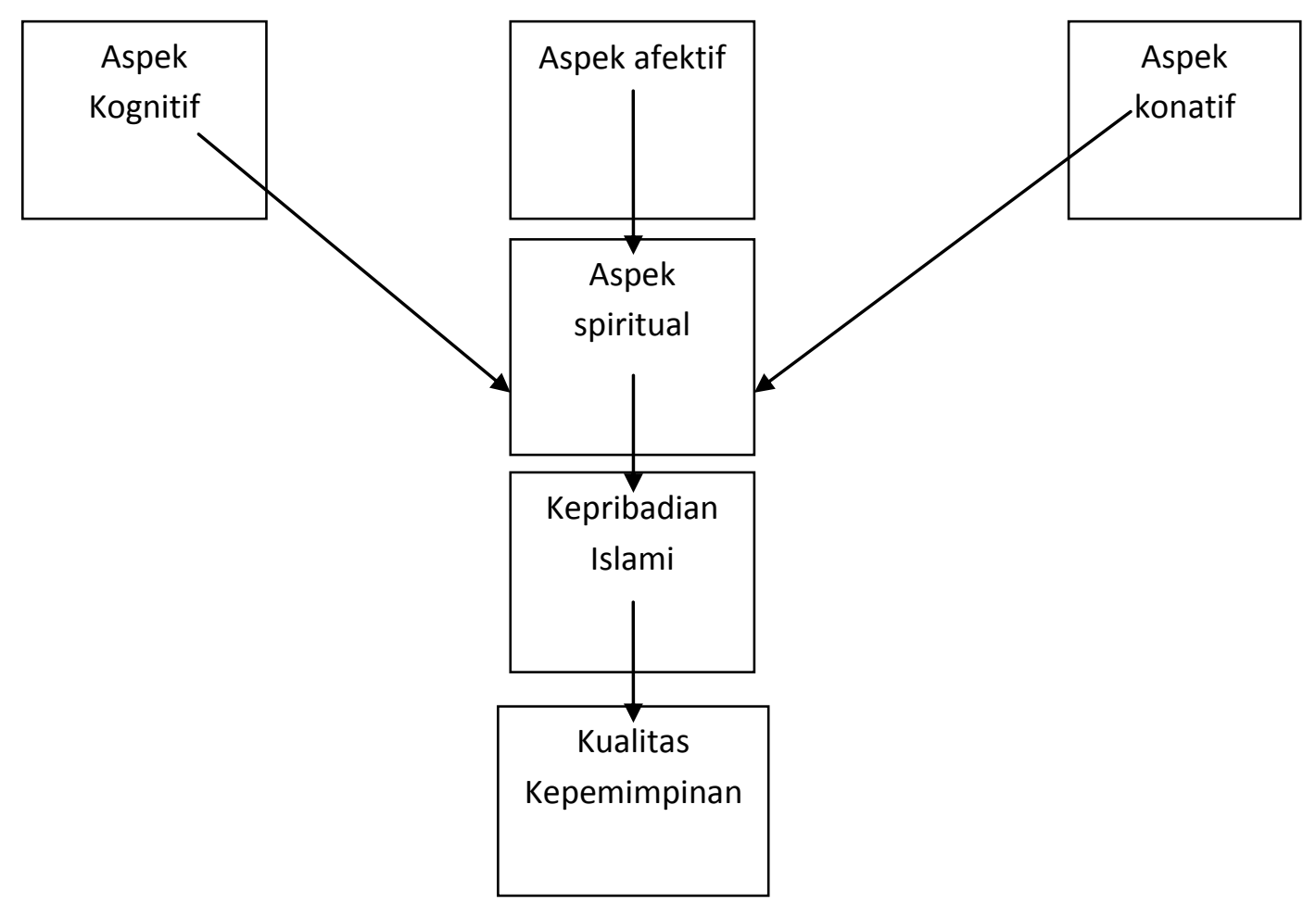

\section{Daftar Pustaka}

Muallifah. 2009. Psycho. Islamic Smart Parenting. Yogyakarta: Diva Press.

Bantinie, S. M. 2010. Kekuatan Berpikir Positif. Memaparkan Fakta-Fakta Ilmiah dan Manfaat

Luar Biasa dari Berpikir Positif untuk Meraih Hidup Bahagia dan Sukses. Jakarta: PT. Wahyumedia.

Frager, Robert.2014. Psikologi Sufi. Untuk Transformasi Hati, Jiwa, dan Ruh. Jakarta: Penerbit Zaman.

Riyono, Bagus.2012. Motivasi dengan Perspektif Psikologi Islam. Yogyakarta: Quality Publishing.

Jaenudin, Ujam. 2102. Psikologi Transpersonal.Bandung: CV. Pustaka Setia.

Ancok, Djamaludin. 2004. Psikologi terapan. Mengupas Dinamika Kehidupan Umat Manusia. Yogyakarta: Darussalam.

Ancok, Djamaludin. 2012. Psikologi kepemimpinan dan Inovasi. Jakarta: Penerbit Erlangga.

Hasan, T,M. 2004. Dinamika Kehidupan Religius. Jakarta: PT. Listafariska Putra.

Burke, dkk. 2011. "Faith in the Wake of Homicide: Religious Coping and Bereveament Distress in Afrika American Sample". The International Journal for the Psychology of Religion, 21:289-307, 2011.

Ward, Collen. 2010. "Acculturation, Identity, and Adaptation in Dual Heritage Adolescents. Journal of Social Psychology".

Haryanto, S. ( 2005). Psikologi Shalat. Kajian Aspek-Aspek Psikologis Ibadah Shalat. Yogyakarta: PT. Pustaka Pelajar

www.id-id.facebook.com/smpislamterpadu.com 